Article

\title{
Preserved Microarrays for Simultaneous Detection and Identification of Six Fungal Potato Pathogens with the Use of Real-Time PCR in Matrix Format
}

\author{
Maksim Nikitin ${ }^{1}{ }^{1}$, Ksenia Deych ${ }^{1}$, Inessa Grevtseva ${ }^{1}$, Natalya Girsova ${ }^{2}$, Maria Kuznetsova ${ }^{2}$, \\ Mikhail Pridannikov ${ }^{2,3}{ }^{-}$, Vitaly Dzhavakhiya ${ }^{2}$, Natalia Statsyuk ${ }^{2, *} \mathbb{C}^{-}$and Alexander Golikov ${ }^{1}$ \\ 1 GenBit LLC, Nauchny pr., 20, Bld. 4, Moscow 117246, Russia; nikitin@genbitgroup.com (M.N.); \\ ksedeych@gmail.com (K.D.); grevtseva@genbitgroup.com (I.G.); golikov@genbitgroup.com (A.G.) \\ 2 All-Russian Research Institute of Phytopathology, Institute Str., 5, Bolshie Vyazemy 143050, Russia; \\ ngirsova@yandex.ru (N.G.); kuznetsova@vniif.ru (M.K.); mikhail.pridannikov@yahoo.com (M.P.); \\ dzhavakhiya@yahoo.com (V.D.) \\ 3 Centre of Parasitology, Severtsov Institute of Ecology and Evolution, Russian Academy of Sciences, \\ Leninskii Prospect 33, Moscow 119071, Russia \\ * Correspondence: nataafg@gmail.com; Tel.: +7-916-304-6235
}

Received: 8 November 2018; Accepted: 11 December 2018; Published: 13 December 2018

\begin{abstract}
Fungal diseases of plants are of great economic importance causing 70-80\% of crop losses associated with microbial plant pathogens. Advanced on-site disease diagnostics is very important to maximize crop productivity. In this study, diagnostic systems have been developed for simultaneous detection and identification of six fungal pathogens using 48-well microarrays (micromatrices) for qPCR. All oligonucleotide sets were tested for their specificity using 59 strains of target and non-target species. Detection limit of the developed test systems varied from 0.6 to $43.5 \mathrm{pg}$ of DNA depending on target species with reproducibility within $0.3-0.7 \%$ (standard deviation). Diagnostic efficiency of test systems with stabilized and freeze-dried PCR master-mixes did not significantly differ from that of freshly prepared microarrays, though detection limit increased. Validation of test systems on 30 field samples of potato plants showed perfect correspondence with the results of morphological identification of pathogens. Due to the simplicity of the analysis and the automated data interpretation, the developed microarrays have good potential for on-site use by technician-level personnel, as well as for high-throughput monitoring of fungal potato pathogens.
\end{abstract}

Keywords: plant pathogen diagnostics; qPCR microarrays; potato; Spongospora subterranea; Rhizoctonia solani; Alternaria solani; Alternaria alternata; Colletotrichum coccodes; Fusarium spp.

\section{Introduction}

Potato is the fourth main staple crop in the world with global production exceeding 375 million metric tons in 2016 [1]. The crop is grown in more than 100 countries and is crucial for welfare of billions of people, so its sustainable production is extremely important for global food security. However, potato suffers from a number of pests and diseases that cause significant yield reduction. Estimated actual potato yield losses caused by the above-mentioned biotic factors comprise $40 \%$ [2]. Among those $14 \%$ is caused by various microbial diseases [3].

Fungi and oomycetes form a significant part of economically important microbial pathogens; they may cause up to $70-80 \%$ of losses resulted from microbial diseases globally [2]. In the case of potato, most economically important diseases of such origin are: late blight caused by Phytophthora infestans (Mont.) de Bary (annual global yield losses of 16\%, though may reach 70-100\% in the case of insufficient protection [4]); stem canker and black scurf caused by Rhizoctonia solani Kühn (up to 30\% 
of marketable yield losses [5]); powdery scab caused by Spongospora subterranea (Wallr.) Lagerh. f. sp. subterranea J. A. Toml. (\$13.4 M of estimated annual losses in Australia alone [6]); wart disease caused by a quarantine pest Synchytrium endobioticum (up to 50-100\% of yield losses on susceptible cultivars [7]); early blight/brown spot disease complex caused by Alternaria solani (Ellis and G. Martin) L.R. Jones and A. alternata (Fr.) Keissl. (up to $40 \%$ yield losses [8]); black dot caused by Colletotrichum coccodes (Wallr.) S.J. Hughes (up to 22-30\% of yield losses [9]); dry rot of tubers caused by several Fusarium species (up to $25 \%$ storage losses [10]), etc.

Advanced disease diagnostics are very important to minimize disease-induced potato losses during production and storage, and to enhance crop productivity. Sensitive and accurate detection of potato pathogens provides for appropriate diseases' control and prevents their outbreaks and spread; comprehensive diagnostics is also very important in case of latent or masked infections, or when visual discrimination between different diseases is complicated. Thus, visual discrimination between common scab (Streptomyces spp.) and much more dangerous powdery scab (Spongospora subterranea) can be difficult, since mature lesions of common scab are often confused with powdery scab manifestations [11]. In addition, correct diagnostics can provide proper plan of pesticide application, thus avoiding unnecessary treatments in case, when visual signs of infection may be confused with those from any abiotic factor; e.g., leaf lesions caused by early blight are very similar to the symptoms of ozone toxicity or deficiency in some microelements, such as manganese, zinc, and magnesium [12].

Traditional diagnostics of microbial pathogens is based on visual observation and characterization of symptoms followed by microscopic examination and culture-based morphological approaches. These methods are time-consuming, laborious, and require advanced skills in taxonomy and morphology of pathogens. Molecular-based direct detection techniques, such as immunoassay and polymerase chain reaction (PCR), permit more sensitive, accurate, and faster identification of pathogens. PCR-based technologies provide high sensitivity and specificity of pathogen identification and are most popular nowadays. They include conventional PCR, real-time PCR, nested PCR, reverse-transcription PCR, multiplex PCR, etc. [13]. Technologies based on monoclonal antibodies (ELISA and lateral flow devices (LFD)) are also widely used in plant pathogen diagnostics; e.g., the number of ELISA tests used yearly for this purpose worldwide reaches $10 \mathrm{M}$ [14]. Some other technologies suitable for accurate identification of plant pathogens in stationary diagnostic laboratories have been developed, including immunofluorescent assay and DNA arrays [15-18].

Current climatic changes occurring in many regions affect plant resistance to pathogens, have an impact on the incidence and severity of potato diseases, and, along with globalization of international trade, provoke changes in their virulence and aggressiveness, as well as invasion of pathogens (including quarantine species) into new areas $[19,20]$. Under such conditions, early and rapid disease diagnostics becomes especially important as a tool to prevent or localize disease outbreaks and choose optimal and accurate control strategies. In the case of quarantine pests or the risk of epidemics, loss of time caused by necessity to send suspicious samples to stationary diagnostic laboratories and to receive answer in 2-3 days, or even 1-2 week (if the laboratory is located far from the field that is a common situation for developing countries), can be crucial and inadmissible. Thus, reliable and sensitive diagnostic tools suitable for use by unskilled personnel, field laboratories, or on-the-spot directly are of great demand. For end users, such diagnostic systems should fit the following criteria:

- cost of analysis should not be too high;

- $\quad$ analysis should be rapid, sensitive and specific;

- multiplex detection of a number of pathogens; and

- procedure of analysis should be simple and does not require special facilities and conditions;

- diagnostic kits should not fall under special storage and transportation limitations.

Most conventional methods for plant pathogens diagnostics do not completely meet these requirements. LFD use is rapid, very simple, and perfectly suited for on-the-spot application. However, like other immunodetection technologies, this method is less sensitive in relation to bacteria and fungi, 
has some cross-reactivity issues, and, until recently, did not provide multiplexity [21]. The cost of ELISA and IFA diagnostic kits is usually higher than for PCR-based technologies, while their shelf life is limited and requires special storage conditions [13]. PCR-based techniques require skilled personnel, are sensitive to cross-contamination and conditions of DNA isolation and amplification, and provides only limited multiplexing; in addition, PCR reagents also require special storage conditions, while equipment is often expensive and does not suit field laboratories [13,22]. DNA arrays provide excellent multiplexity but are used in stationary labs only.

Since all the above methods have drawbacks, a lot of efforts are made to improve these approaches or to develop alternative simple, reliable, and efficient field diagnostic techniques. Multiplex LFD [23], real-time PCR on portable amplifiers [24,25], simplification of DNA/RNA isolation technologies [26,27], LAMP PCR [28], various biosensors based on antibodies and DNA probes [29,30], and also microfluidic and stationary microchip PCR systems [31] are among the most promising.

In the case of potato, commercial kits currently available for disease diagnostics, directly on-the-spot or in field laboratories, are represented mainly by LFD and ELISA kits for detection of various potato viruses, some bacteria, and several fungi and oomycetes. There are also some FLASH PCR [32] kits suitable for detection of potato viruses and some bacteria and quarantine nematodes, as well as numerous real-time PCR kits for detection of a number of potato pathogens of different origin. In the case of fungi, the range of commercial diagnostic kits is quite limited and includes ELISA or LFD kits for detection of P. infestans, $R$ solani, and S. subterranea, as well as several PCR kits for detection of S. endobioticum and some Fusarium species. However, all these tools are based on the "one test-one pathogen" principle, i.e., they do not provide simultaneous diagnostics of multiple pathogens. Despite some reports on the development of multiplex LFD or PCR systems for the detection of a number of potato pathogens $[23,33,34]$, these systems are not commercialized yet, i.e., they exist at the laboratory-scale only.

The given study presents a project started by the authors to provide an easy and convenient tool for multiplex field diagnostics of a wide range of potato pathogens based on the use of preserved disposable stationary qPCR microarrays with open microreactors. A special technology of immobilization and lyophilization of PCR mix components on the surface of reaction wells (provided by GenBit LLC, one of the partners in the project) and automatic analysis of results made it possible to significantly simplify the procedure of analysis: an operator should only prepare DNA/RNA extract and apply it into reaction wells of the multi-target matrix (sensor) under the sealing layer of mineral oil. In addition, this technology provides a long-term (up to six months) storage of preserved microarrays at room temperature without significant reduction of their analytic efficiency [35]. To date, test systems have been developed for the detection and identification of a range of potato pathogens, including eight viruses, six bacteria, four nematodes, and one oomycete [35-37]. The purpose of this study was the development of similar diagnostic systems for detection and identification of six economically important fungal pathogens of potato (A. solani, A. alternata, $R$ solani, C. coccodes, S. subterranea, and fungi belonging to the genus Fusarium).

\section{Materials and Methods}

\subsection{Fungal Isolates, Cultivation, and DNA Extraction}

Fungal isolates used in this study were provided by the State Collection of Plant Pathogenic Microorganisms, Indicator Plants and Differential Cultivars (SCPPM) of the All-Russian Research Institute of Phytopathology (Bolshie Vyazemy, Russia) and the "Microorganisms and Fungi" Division of the "Noah's Ark" living systems depository of the Lomonosov Moscow State University (Moscow, Russia), and are listed in Table 1.

The ordered microorganisms were obtained from above-mentioned collections on agar slants. Petri plates with potato-dextrose agar were inoculated by pieces of mycelium and incubated for 5-10 days at room temperature in the dark. Genomic DNA was extracted from fungal mycelium using 
AmpliSens Ribo-Sorb DNA/RNA extraction kit (Russian Central Institute of Epidemiology, Moscow, Russia) in accordance with the manufacturer's recommendations.

Table 1. Fungal isolates used in this study.

\begin{tabular}{|c|c|c|c|c|}
\hline Species & Isolate Code & Year and Region of Collection & Host Plant & Source $^{1}$ \\
\hline Alternaria solani & 100053 & 2009, Mariy El Republic, Russia & Potato & SCPPM \\
\hline A. solani & 043-021 & -2 & - & MF \\
\hline A. solani & 044-051 & - & - & MF \\
\hline A. alternata & $41 / 6$ & 2011, Republic of Mordovia, Russia & Barley & SCPPM \\
\hline A. alternata & $4 \mathrm{k} / 2$ & 2011, Republic of Mordovia, Russia & Barley & SCPPM \\
\hline A. alternata & AK2 & - & - & MF \\
\hline A. alternata & HKK1 & - & - & MF \\
\hline A. alternata & 12RKL9 & 2007, Ryazan region, Russia & Potato & MF \\
\hline A. alternata & 12RKL10 & 2007, Ryazan region, Russia & Potato & MF \\
\hline A. infectoria & K100088 & 2009, Krasnodar region, Russia & Bindweed & SCPPM \\
\hline A. radicina & K100011 & 2009, Moscow region, Russia & Carrot & SCPPM \\
\hline A. longipes & K100055 & 2000, Moscow region, Russia & Tomato & SCPPM \\
\hline Rhizoctonia solani & 100006 & 2005, Moscow region, Russia & Potato & SCPPM \\
\hline$R$ solani & 100063 & 2011, Moscow region, Russia & Potato & SCPPM \\
\hline$R$ solani & 100106 & 2013, Leningrad region, Russia & Potato & SCPPM \\
\hline$R$ solani & R15BKK nev25 & 2015, Vladimir region, Russia & Potato & SCPPM \\
\hline$R$ solani & 14BM rs2 & 2014, Vladimir region, Russia & Potato & SCPPM \\
\hline$R$ solani & $14 \mathrm{KC} \operatorname{man} 1$ & 2014, Kostroma region, Russia & Potato & SCPPM \\
\hline R. cerealis & 1000025 & 2009, Ryazan region, Russia & Spring wheat & SCPPM \\
\hline Colletotrichum coccodes & 100004 & 2009, Moscow region, Russia & Potato & SCPPM \\
\hline C. coccodes & 100123(3) & 2012, Voronezh region, Russia & Potato & SCPPM \\
\hline C. coccodes & 100124(3) & 2013, Tula region, Russia & Potato & SCPPM \\
\hline C. coccodes & 100119(3) & 2015, Orenburg region, Russia & Potato & SCPPM \\
\hline C. coccodes & 100120(3) & 2015, Moscow region, Russia & Potato & SCPPM \\
\hline C. coffeanum & 100003 & 2008, Moscow region, Russia & Ornamental plants & SCPPM \\
\hline C. gloeosporioides & 100002 & 2009, Bryansk region, Russia & Blue lupine & SCPPM \\
\hline C. gloeosporioides & 100094 & 2013, Moscow region, Russia & Tatarian honeysuckle & SCPPM \\
\hline C. lilii & 100001 & 2009, Moscow region, Russia & Lily & SCPPM \\
\hline C. dematium & 100158 & 2017, Republic of Mordovia, Russia & Barley & SCPPM \\
\hline Fusarium avenaceum & MOK-16-3 & 2016, Moscow region, Russia & Potato & SCPPM \\
\hline F. avenaceum & 110501 & 2003, Moscow region, Russia & Barley & SCPPM \\
\hline F. avenaceum & U-08-8-1 & 2008, Ulyanovsk region, Russia & Wheat & SCPPM \\
\hline F. culmorum & MKRS-15-3 & 2015, Moscow region, Russia & Potato & SCPPM \\
\hline F. culmorum & $100135(6-1)$ & 2009, Moscow region, Russia & Potato & SCPPM \\
\hline F. culmorum & $100136(6-2)$ & 2009, Moscow region, Russia & Potato & SCPPM \\
\hline F. gibbosum & $100130(7-2)$ & 2014, Moscow region, Russia & Potato & SCPPM \\
\hline F. gibbosum & $100131(7-2)$ & 2014, Moscow region, Russia & Potato & SCPPM \\
\hline F. gibbosum & $100132(7)$ & 2009 , Voronezh region, Russia & Potato & SCPPM \\
\hline F. heterosporum & MOK-16-1 & 2016, Moscow region, Russia & Potato & SCPPM \\
\hline F. heterosporum & 100133(8) & 2009, Moscow region, Russia & Potato & SCPPM \\
\hline F. oxysporum & FO-1 & 1995, Moscow region, Russia & Potato & SCPPM \\
\hline F. oxysporum & 100139(9) & 2014, Moscow region, Russia & Potato & SCPPM \\
\hline F. oxysporum & 100140(9) & 2013, Bryansk region, Russia & Potato & SCPPM \\
\hline F. oxysporum & RAM-14 & 2014, Moscow region, Russia & Potato & SCPPM \\
\hline F. sambucinum & P-2-02 & 2002, Ryazan region, Russia & Barley & SCPPM \\
\hline F. sambucinum & KRT 11-1 kch & 2012, Krasnodar region, Russia & Wheat & SCPPM \\
\hline F. sambucinum & $100134(10)$ & 2009, Lipetsk region, Russia & Potato & SCPPM \\
\hline F. solani & FSL-9 & 2002, Moscow region, Russia & Potato & SCPPM \\
\hline F. solani & 100021 & 2001, Moscow region, Russia & Potato & SCPPM \\
\hline F. solani & $100137(11-1)$ & 2009, Moscow region, Russia & Potato & SCPPM \\
\hline F. solani & $100138(11-2)$ & 2009, Moscow region, Russia & Potato & SCPPM \\
\hline F. sporotrichioides & KRT12-1kch & 2012, Krasnodar region, Russia & Wheat & SCPPM \\
\hline F. sporotrichioides & $100141(12)$ & 2009, Moscow region, Russia & Potato & SCPPM \\
\hline F. javanicum & MKRS-15-1 & 2015, Moscow region, Russia & Potato & SCPPM \\
\hline F. sacchari & RAM-16 & 2016, Moscow region, Russia & Potato & SCPPM \\
\hline Phytophthora infestans & MVK 118a-07 & 2007, Moscow region, Russia & Potato & SCPPM \\
\hline P. infestans & ATP-3.08 & 2008, Astrakhan region, Russia & Tomato & SCPPM \\
\hline
\end{tabular}

1 SCPPM: State Collection of Plant Pathogenic Microorganisms of the All-Russian Research Institute of Phytopathology, Bolshie Vyazemy, Russia; MF: “Microorganisms and Fungi" Division of the "Noah's Ark" living systems depository of the Lomonosov Moscow State University, Moscow, Russia. ${ }^{2}$ Not available.

For extraction, a portion of mycelium with the upper layer of agar medium was collected from the area of $\sim 1 \mathrm{~cm}^{2}$. DNA yield and purity were determined spectrophotometrically at $260 \mathrm{~nm}$ using a 
SmartSpec Plus spectrophotometer (BioRad, Berkeley, CA, USA). Obtained DNA samples were stored at $-20^{\circ} \mathrm{C}$ until use.

Since S. subterranea is an obligate intracellular parasite, isolation and maintenance of this pathogen in a pure culture is impossible [38]. Due to this fact, examination of the test system developed for detection of this pathogen, was carried out using samples of pathogen DNA isolated from two potato tubers (cvs. Red Scarlett and Colomba) infected with S. subterranea (Sss-RS and Sss-C, respectively). Tubers with visible signs of infection (pustules filled with powder-like brown spore mass) were revealed at the Leningrad regional branch of the Federal State Budgetary organization "Russian Agricultural Center" during analysis of a seed potato lot imported from Finland in 2017; analysis was carried out within the framework of a seed potato certification. Results of visual examination were then confirmed by microscopic examination of thin sections of infected tuber tissues for detection of spore balls. DNA isolation from samples with a confirmed presence of $S$. subterranea was performed as described above.

\subsection{Oligonucleotide Design}

To provide flexibility of microarray composition, the developed test systems should be efficient under the same "standard" amplification conditions and temperatures (see Section 2.4); this fact stipulated necessity to develop original primers and probes. PCR primers and fluorescent probes for each target pathogen were designed based on the internal transcribed spacer (ITS) region (R. solani, S. subterranea), Alt_a1 gene (A. solani, A. alternata), EF1 gene (Fusarium sp.), and Tub2 gene (C. coccodes) using corresponding gene sequences from the NCBI database [39]. The sequences were aligned using a CLUSTAL 0(1.2.4) algorithm. Primer design and selection of a specific probe and reaction conditions were carried out using the Oligo 6 program [40]. Search of appropriate DNA region for primer and probe sequences was carried out using the following conditions: the length of resulting amplicons should be 70-300 bp, the preferable annealing temperature $\left(\mathrm{T}_{\mathrm{a}}\right)$ should be $60{ }^{\circ} \mathrm{C}$, the difference in melting temperatures should not exceed $3^{\circ} \mathrm{C}$, and the number of mismatches between the amplified sequence and primers should not exceed 2. Additionally, possible dimer or hairpin formation was evaluated for each set of oligonucleotides. Theoretical examination of specificity of each primer pair was performed using a BLAST algorithm [41].

The resulted primers, as well as the probes for each primer pair labeled with $5^{\prime}$-fluorescent dye (FAM or ROX) and a 3'-quencher (BHQ-1 or BHQ-2), were manufactured by Biotech-Industria LLC. (Moscow, Russia). The length of resulted amplicons was evaluated with gel electrophoresis in $1 \%$ agarose with ethidium bromide staining.

\subsection{Sample Preparation}

For preliminary evaluation of the test system efficiency in a tube format, PCR master mix of total $20 \mu \mathrm{L}$ consisted of $0.6 \mu \mathrm{L}$ of dNTP mix $(10 \mathrm{mM}), 2 \mu \mathrm{L}$ of the oligonucleotide mix ( $5 \mathrm{pmol} / \mu \mathrm{L}$ of each primer and $2.5 \mathrm{pmol} / \mu \mathrm{L}$ of a probe); $2.5 \mu \mathrm{L}$ of a $10 \times \mathrm{Mg}^{2+}$-containing PCR buffer, $0.9 \mu \mathrm{L}$ of Taq DNA polymerase ( $5 \mathrm{U} / \mu \mathrm{L}$, Sibenzyme Ltd., Novosibirsk, Russia), and $14 \mu \mathrm{L}$ of DNase/RNase-free deionized water was prepared in 0.2-mL tubes. Five microliters of template DNA $(\sim 30-50 \mu \mathrm{g} / \mathrm{mL})$ or deionized water (negative control) was added to PCR mastermix, and the resulted sample was analyzed using a DTLite 4 amplifier (DNK-Tekhnologiya, Moscow, Russia).

At the second stage of the study (sensitivity, specificity and reproducibility tests), PCR analysis was carried out using empty 48-well silicon microarrays (GenBit LLC, Moscow, Russia). After installation of a microarray into a holder cartridge, the whole reaction zone was accurately covered with a sealing layer of mineral oil $(620 \mu \mathrm{L})$. For each test system, the above-mentioned PCR master mix was prepared in a volume corresponding to a number of required reaction wells. After addition of template DNA or deionized water (negative control), $1 \mu \mathrm{L}$ of PCR mix was accurately loaded into each reaction well under the oil layer. A cartridge with the loaded microarray was inserted into an AriaDNA ${ }^{\circledR}$ microchip amplifier (Lumex Marketing LLC, St.-Petersburg, Russia) for further real-time PCR. 
At the third stage, the final testing was carried out using preserved 48-well silicon microarrays containing preliminary stabilized and freeze-dried components (master mixes, except for PCR buffer and target DNA) of the examined test systems (Figure 1). Preparation of the preserved microrrays was carried out by the GenBit LLC according to [42] with some modifications using a special technology developed independently of this study. Template DNA samples were mixed with $10 \times$ PCR buffer (Sibenzyme Ltd., Novosibirsk, Russia) at a 1:9 ratio; the resulting DNA concentration was $\sim 1 \mu \mathrm{g} / \mathrm{mL}$. After installation of a microarray into a holder cartridge and covering reaction zone with $620 \mu \mathrm{L}$ of mineral oil, $1 \mu \mathrm{L}$ of a sample DNA or deionized water (negative control) was added into each well under the sealing oil layer according to the particular matrix topology. Ready microarrays were inserted into an AriaDNA ${ }^{\circledR}$ microarray amplifier for further real-time PCR.

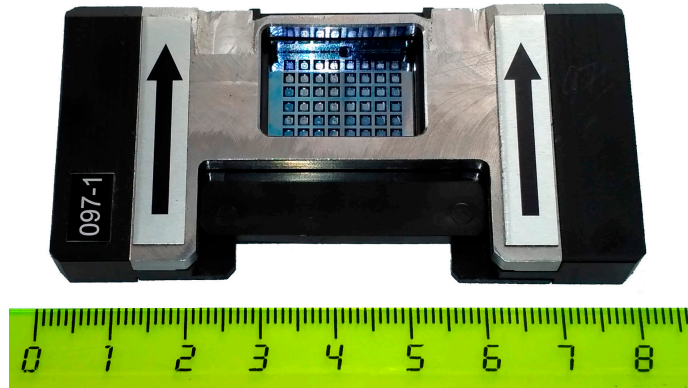

(a)

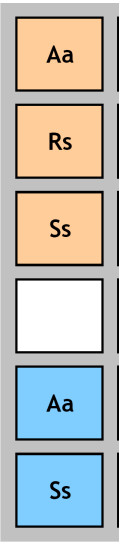

Fs
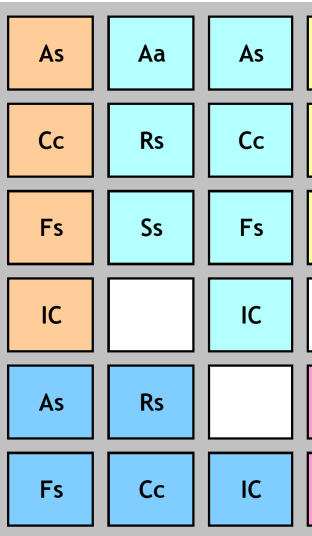

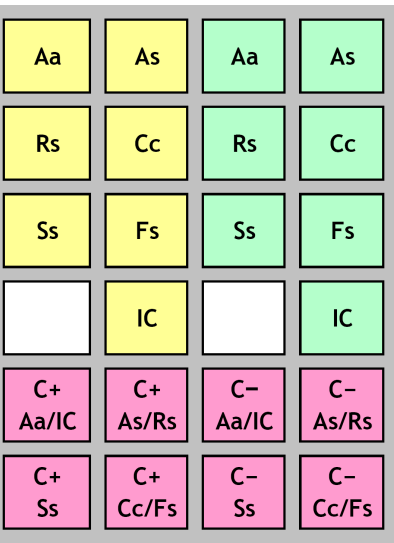

(b)

Figure 1. Microarray designed for diagnostics of fungal pathogens of potato: (a) 48-well microarray in a holder (the numbers on the ruler represent centimeters); (b) microarray topology for simultaneous analysis of five samples (shown by different colors). Indications: Aa, Alternaria alternata; As, Alternaria solani; Rs, Rhizoctonia solani; Cc, Colletotrichum coccodes; Ss, Spongospora subterranea; Fs, Fusarium spp.; IC, internal control sample; $\mathrm{C}+$, positive control; $\mathrm{C}-$, negative control.

\subsection{Amplification Conditions and Data Analysis}

The standard thermal cycling conditions for DNA amplification included initial denaturation step at $94{ }^{\circ} \mathrm{C}$ for $180 \mathrm{~s}$ followed by 45 cycles at $94{ }^{\circ} \mathrm{C}$ for $5 \mathrm{~s}$ and $60{ }^{\circ} \mathrm{C}$ for $30 \mathrm{~s}$. The total amplification time was $\sim 30 \mathrm{~min}$. Data acquisition was automatically performed at the end of each cycle. The baseline was set in an automatic mode. Signal recording, calculation of critical threshold cycles $\left(\mathrm{C}_{t}\right)$, and analysis of results were carried out automatically using an AriaDNA ${ }^{\circledR}$ software package (Lumex-Marketing LLC, St.-Petersburg, Russia).

\subsection{Validation of Developed qPCR Assays}

The test systems were validated in several steps. First, for each target pathogen, the specificity of primer pairs was tested with 59 DNA samples of related and other target species, as well as with DNA samples of two different isolates of Phytophthora infestans (oomycete pathogen of potato, primer set for which has been developed earlier [35] and is planned to be added to the set of fungal pathogens of potato). All samples used were adjusted to final DNA concentration 1-10 $\mu \mathrm{g} / \mathrm{mL}$; DNA of each species was tested in three repeats.

Subsequently, sensitivity of the developed test systems was determined using 5-6 of 10-fold serial dilutions of DNA extracted from pure cultures of the target species. DNA of each species was tested in three repeats for each concentration; all dilutions were arranged in the same microarray. According to the earlier report [35], we considered 35 to be the limit value of $C_{t}$. With $C_{t}$ above this value one cannot judge whether it is a false positive result or just a very low DNA presence. 
Reproducibility of the approach was examined by analysis of the same sample of each target pathogen in 9 or 14 replications arranged on the same preserved microarray. DNA concentration used in this assay was adjusted to $1 \mu \mathrm{g} / \mathrm{mL}$.

Finally, the assays were examined using 30 naturally infested field samples of potato and tomato. Leaves, stems, and tubers with visible manifestations of infection with target pathogens were collected from potato fields in several regions of Russia (see Section 3.6 for details). For each lesion one tissue sample was taken in the way so it included both infested and neighboring healthy tissues. DNA extraction from plant tissues was carried out as described in Section 2.1 for fungal mycelium; PCR analysis was performed as described in Section 2.4. Results of the analysis were compared with the results obtained by morphological identification of fungi [43].

\section{Results}

\subsection{Primer Design}

The best oligonucleotide set for each target species was selected (Table 2) upon alignment of DNA sequences (Figures S1-S3). The length of the resulted amplicons corresponded to the calculated values (data not shown).

Table 2. Species-specific primers and probes designed for the qPCR-based diagnostics of six fungal pathogens of potato.

\begin{tabular}{|c|c|c|c|c|}
\hline Test System & Primers and Probe Sequences $\left(5^{\prime}-3^{\prime}\right)$ & Length, Bases & $\mathrm{T}_{\mathrm{m}}{ }^{*},{ }^{\circ} \mathrm{C}$ & Amplicon Size, bp \\
\hline \multirow{3}{*}{$\begin{array}{l}\text { Asol4 } \\
\text { Alternaria solani }\end{array}$} & F: GGTCAGCGACGAGTAAGTT & 19 & 59.4 & \multirow{3}{*}{71} \\
\hline & R: CAGATATACTAACGCTTTTCCA & 22 & 60 & \\
\hline & Probe: ROX-CACGCTTTTCACCACCTTTTAC-BHQ2 & 22 & 66.7 & \\
\hline \multirow{3}{*}{$\begin{array}{l}\text { Aalt1 } \\
\text { Alternaria alternata }\end{array}$} & F: AGGAACCCTCGACTTCACCT & 20 & 62.0 & \multirow{3}{*}{75} \\
\hline & R: TTCTCGCCACAGGAGTACCA & 20 & 62.0 & \\
\hline & Probe: FAM- CTCTGCTCAGGCCGATAAGCT-BHQ1 & 21 & 66.0 & \\
\hline $\begin{array}{l}\text { Rsol4 } \\
\text { Rhizoctonia solani }\end{array}$ & Probe: FAM-TGCTTGGTTCCACTCAGCG-BHQ1 & 19 & 67.2 & 128 \\
\hline \multirow{3}{*}{$\begin{array}{l}\text { Ccoc } \\
\text { Colletotrichum coccodes }\end{array}$} & F: ACTTGTTCGAATAGGGTAACC & 21 & 60.5 & \multirow{3}{*}{115} \\
\hline & R: TAGGGCACAGTCAGTAATTCA & 21 & 60.5 & \\
\hline & Probe: FAM-AACCAGACAGACGCCAACGA-BHQ1 & 20 & 68.5 & \\
\hline $\begin{array}{l}\text { Sss } \\
\text { Spongospora subterranea }\end{array}$ & F: GCCTCTTTGAGTGTCGGTT & 19 & 62 & 124 \\
\hline $\begin{array}{l}\text { Fus } \\
\text { Fusarium spp. }\end{array}$ & Probe: FAM-TGAGCTTGTCAAGAACCCAGG-BHQ1 & 21 & 67 & 369 \\
\hline
\end{tabular}

* Theoretical melting temperature.

Preliminary testing of the developed test systems in tube format showed their sufficient working capacity; all systems successfully detected target fungal species (data not shown). Each test system was then examined using the same sample DNA at four different annealing temperatures $\left(\mathrm{T}_{\mathrm{a}}\right)$ to evaluate its efficiency at the desired $\mathrm{T}_{\mathrm{a}}\left(60^{\circ} \mathrm{C}\right)$. According to results obtained (Table S1), $\mathrm{T}_{\mathrm{a}}=60^{\circ} \mathrm{C}$ provided satisfactory results for all primer sets, i.e., the test systems were capable to provide good work efficiency under "standard" amplification conditions.

\subsection{Specificity Assay}

All test systems were subjected to specificity examination at both development stage (using NCBI nucleotide-BLAST tool) and through laboratory testing. In the last case, each test system was checked for potential cross-reactions with genomic DNA of a range of the target and related species. For all species-specific primers sets, only DNA samples of target pathogen provided sufficient signal intensity, while signals from other species did not exceed threshold levels; in the case of a genus-specific Fus test system, all Fusarium species included in this study were successfully detected, while samples of other 
species did not show any amplification (Table 3, Figure S4). Thus, no cross-reactions with non-target species or false positive results were observed.

Table 3. Specificity test for individual DNA-based systems for diagnostics of fungal pathogens of potato.

\begin{tabular}{|c|c|c|c|c|c|c|c|}
\hline \multirow{2}{*}{ Species } & \multirow{2}{*}{ Isolate } & \multicolumn{6}{|c|}{$C_{t}$ Values $\left(C_{t} \pm S E\right)$ Obtained for the Pathogens Included into the Specificity Test ${ }^{1}$} \\
\hline & & Asol4 & Aalt1 & Rsol4 & Fus & Ccoc & Sss \\
\hline Alternaria solani & 100053 & $27.23 \pm 0.15$ & - & - & - & - & - \\
\hline A. solani & $043-021$ & $24.79 \pm 0.16$ & - & - & - & - & - \\
\hline Alternaria alternata & $41 / 6$ & - & $20.62 \pm 0.47$ & - & - & - & - \\
\hline A. alternata & $4 \mathrm{k} / 2$ & - & $21.13 \pm 0.90$ & & & & \\
\hline A. alternata & AK2 & - & $21.52 \pm 0.71$ & & & & \\
\hline A. alternata & 12RKL10 & - & $22.93 \pm 0.95$ & & & & \\
\hline A. infectoria & K100088 & - & - & - & - & - & - \\
\hline A. longipes & K100055 & - & - & - & - & - & - \\
\hline Rhizoctonia solani & 100006 & - & - & $16.53 \pm 0.32$ & - & - & - \\
\hline$R$ solani & 100063 & - & - & $12.61 \pm 0.08$ & - & - & - \\
\hline$R$ solani & 100106 & & & $16.29 \pm 1.73$ & & & \\
\hline Colletotrichum coccodes & 100004 & - & - & - & - & $27.85 \pm 0.37$ & - \\
\hline C. coccodes & $100123(3)$ & & & & & $28.14 \pm 0.15$ & \\
\hline C. coccodes & $100124(3)$ & - & - & - & - & $25.24 \pm 0.12$ & - \\
\hline C. coccodes & $100119(3)$ & & & & & $25.94 \pm 0.39$ & \\
\hline C. coccodes & $100120(3)$ & & & & & $24.25 \pm 0.65$ & \\
\hline C. coffeanum & 100003 & - & - & - & - & - & - \\
\hline C. gloeosporioides & 100002 & - & - & - & - & - & - \\
\hline C. gloeosporioides & 100094 & & & & & - & \\
\hline C. lilii & 100001 & & & & & - & \\
\hline C. dematium & 100158 & & & & & - & \\
\hline Fusarium avenaceum & MOK-16-3 & - & - & - & $25.13 \pm 0.10$ & - & - \\
\hline F. avenaceum & 110501 & & & & $32.32 \pm 0.29$ & & \\
\hline F. avenaceum & U-08-8-1 & & & & $23.86 \pm 1.02$ & & \\
\hline F. oxysporum & $100139(9)$ & & & & $26.04 \pm 0.45$ & & \\
\hline F. oxysporum & $100140(9)$ & - & - & - & $25.09 \pm 0.52$ & & \\
\hline F. oxysporum & RAM-14 & & & & $34.02 \pm 0.59$ & & \\
\hline F. sambucinum & $\mathrm{P}-2-02$ & & & & $28.05 \pm 0.16$ & & \\
\hline F. sambucinum & KRT $11-1$ kch & - & - & - & $24.04 \pm 0.08$ & - & - \\
\hline F. sambucinum & $100134(10)$ & & & & $26.05 \pm 0.49$ & & \\
\hline F. solani & FSL-9 & & & & $33.39 \pm 0.78$ & & \\
\hline F. solani & 100021 & - & - & - & $33.72 \pm 0.69$ & - & - \\
\hline F. solani & $100137(11-1)$ & & & & $32.40 \pm 0.52$ & & \\
\hline F. solani & $100138(11-2)$ & & & & $30.62 \pm 1.29$ & & \\
\hline F. sporotrichioides & KRT12-1 kch & & & & $31.96 \pm 1.25$ & & \\
\hline F. sporotrichioides & $100141(12)$ & & & & $32.78 \pm 0.96$ & & \\
\hline F. javanicum & MKRS-15-1 & & & & $33.35 \pm 0.84$ & & \\
\hline F. sacchari & RAM-16 & & & & $33.65 \pm 0.88$ & & \\
\hline Phytophthora infestans & MVK 118a-07 & - & - & - & - & - & - \\
\hline P. infestans & ATP-3.08 & - & - & - & - & - & - \\
\hline Spongospora subterranea & Field sample, Sss-RS & - & - & - & - & - & $21.36 \pm 0.05$ \\
\hline S. subterranea & Field sample, Sss-C & - & - & - & - & - & $20.53 \pm 0.08$ \\
\hline
\end{tabular}

${ }^{1}$ Blank cells indicate strains not included into the assay. "-" indicates zero amplification.

\subsection{Sensitivity Assay and Regression Curves}

Examples of amplification curves obtained for serial dilutions of DNA of target potato pathogens are shown in Table 4 and Figure S5. Standard regression curves generated using serial DNA dilutions showed good linearity (Figure 2) with highly significant negative correlation between $C_{t}$ values and DNA concentrations over the range used $\left(R^{2}>0.99\right.$ for all test systems), i.e., linear dynamic range of 
amplification was exhibited for the concentration ranges used. According the results of the performed assay, the lowest DNA concentrations providing $C_{t}$ value below threshold value $\left(C_{t}=35\right)$, were about 43.5 (Asol4), 3.3 (Aalt1), 18 (Rsol4), 37 (Ccoc), 0.6 (Sss), and 1.7 (Fus) ng/mL. Since the reaction well volume of 48 -well microarrays is $1 \mu \mathrm{L}$, these values corresponded to $43.5,3.3,18,37,0.6$, and $1.7 \mathrm{pg}$ of DNA.

Table 4. Performance of the diagnostic systems for serial dilutions of DNA of target species.

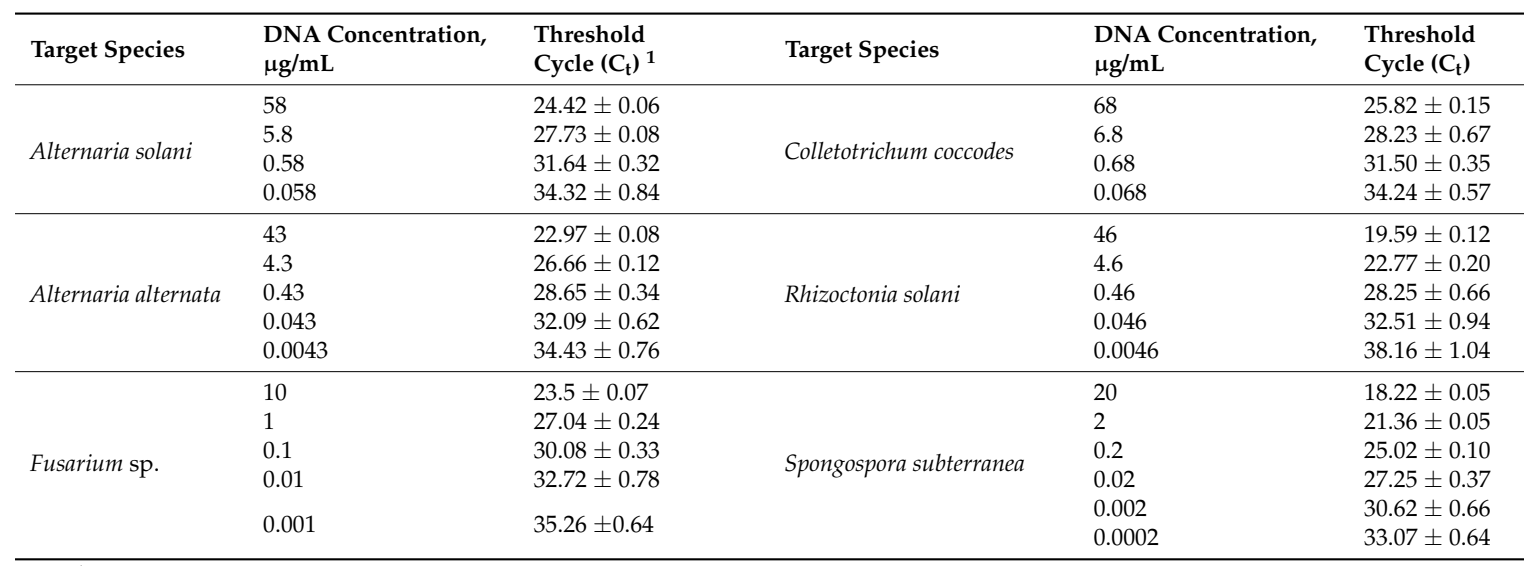

${ }^{1}$ Data are shown in the form of $\mathrm{M} \pm \mathrm{SE}$, where $\mathrm{M}$ is a mean value and $\mathrm{SE}$ is the standard error calculated for three repeats.
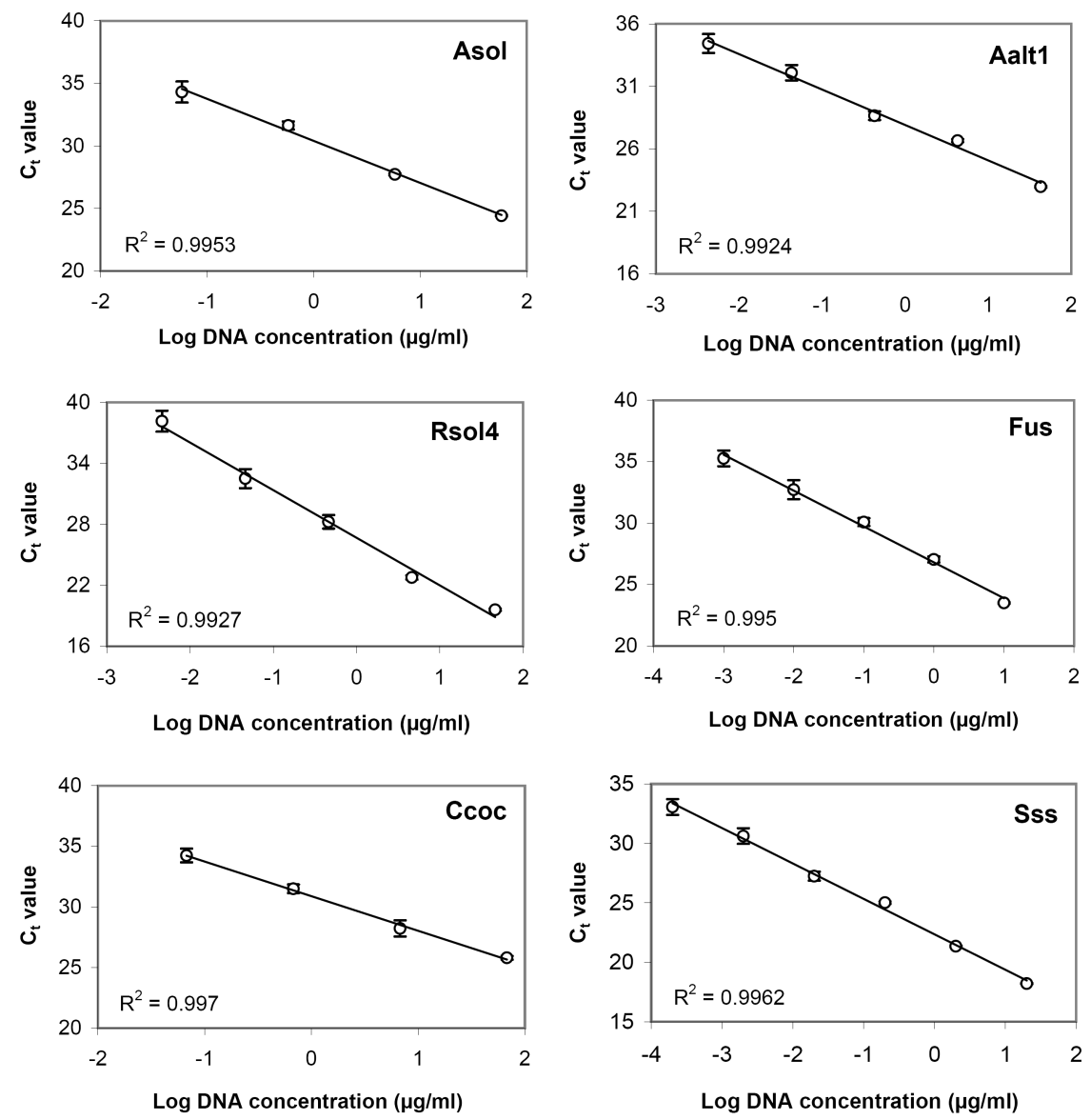

Figure 2. Standard regression curves of serial dilutions of DNA from the target potato pathogens. Test systems designations: Asol4, Alternaria solani; Aalt1, A. alternata; Rsol4, Rhizoctonia solani; Ccoc, Colletotrichum coccodes; Sss, Spongospora subterranea; Fus, Fusarium spp. 


\subsection{Reproducibility Assay}

Results of the reproducibility assay for the developed test systems are shown in Figure 3. Mean $C_{t}$ values are shown in Table 5. All test systems showed a good reproducibility; in all cases, the standard error for $C_{t}$ values did not exceed $1 \%$.

Table 5. Mean $C_{t}$ values obtained for the developed test systems for diagnostics of fungal pathogens of potato (reproducibility assay).

\begin{tabular}{lccc}
\hline Test System & Number of Repeats & $\mathbf{C}_{\mathbf{t}}$ Value (M \pm SE) & SE (\%) \\
\hline Asol4 (Alternaria solani) & 14 & $27.23 \pm 0.10$ & 0.4 \\
Aalt1 (Alternaria alternata) & 14 & $16.20 \pm 0.06$ & 0.3 \\
Rsol4 (Rhizoctonia solani) & 14 & $20.24 \pm 0.08$ & 0.4 \\
Ccoc (Colletotrichum coccodes) & 9 & $27.39 \pm 0.19$ & 0.7 \\
Fus (Fusarium spp.) & 14 & $22.66 \pm 0.09$ & 0.4 \\
Sss (Spongospora subterranea) & 9 & $23.32 \pm 0.17$ & 0.7 \\
\hline
\end{tabular}
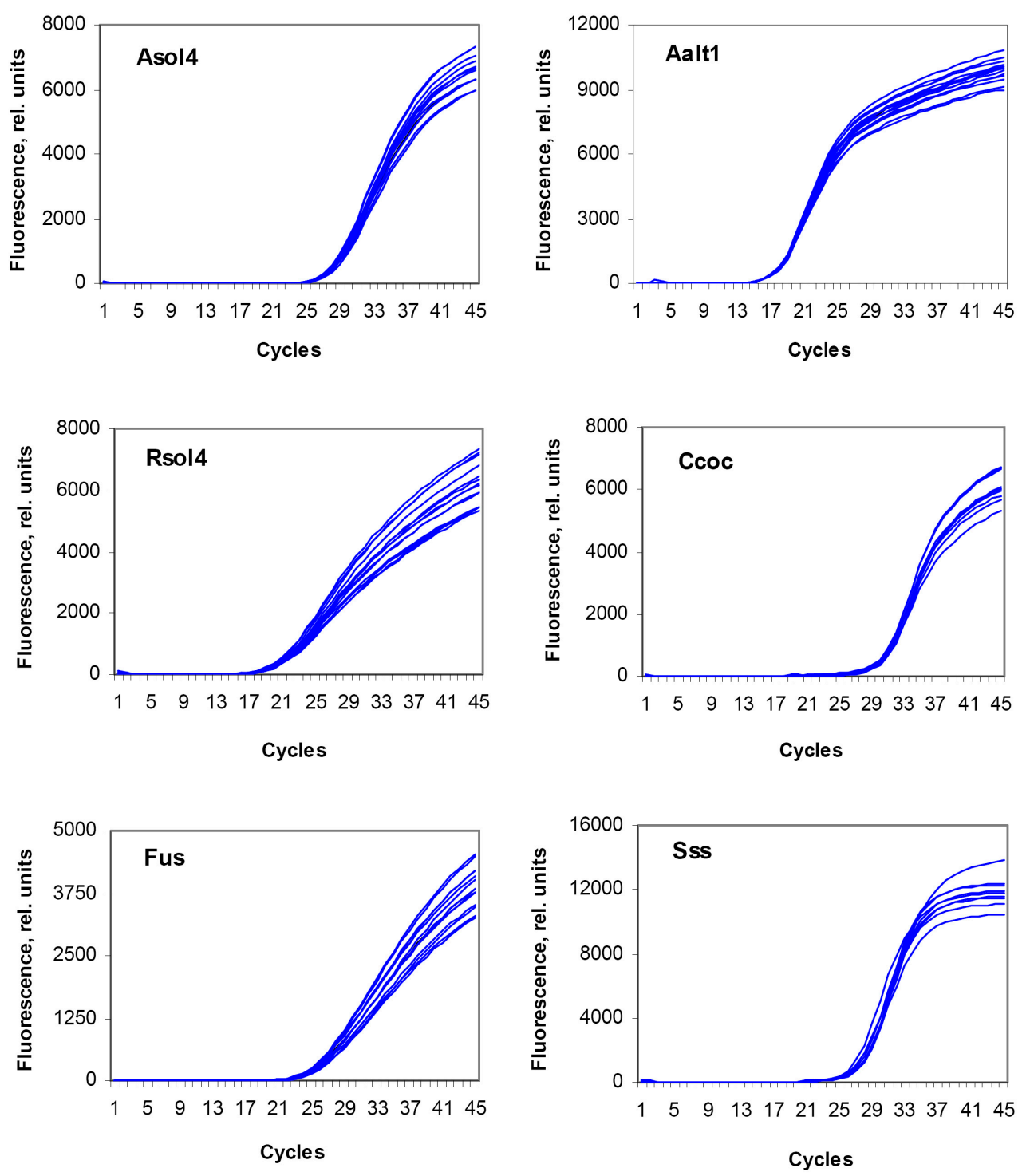

Figure 3. Reproducibility of the test systems for detection of the target potato pathogens. Test systems designations: Asol4, Alternaria solani; Aalt1, A. alternata; Rsol4, Rhizoctonia solani; Ccoc, Colletotrichum coccodes; Sss, Spongospora subterranea; Fus, Fusarium spp. Each species was analyzed in nine (Ccoc, Sss) or 14 (Aalt1, Asol4, Rsol4, Fus) repeats. 


\subsection{Comparison of the Working Efficiency of Fresh and Lyophilized Test Systems}

Comparison of freshly prepared and lyophilized (ready-to-use) silicon microarrays for detection and identification of target potato pathogens was carried out upon completion of specificity, sensitivity, and reproducibility tests. After application of the required PCR components into reaction wells in accordance with the microarray topology (Figure 1b) and their lyophilization, detection efficiency of the resulted microarray was tested using DNA samples of target species; in parallel, the same samples were applied to a freshly prepared (non-lyophilized) microarray. $C_{t}$ values and the round-off fluorescence level at the end of the analysis were used for a comparison. The experiment was carried out in two repeats.

Results are shown in Table 6 and Figure 4. For all test systems, $C_{t}$ values obtained for both fresh and lyophilized microarrays were about the same, varying slightly, while final fluorescence signal of lyophilized test system dropped making $20-50 \%$ of the values obtained for fresh systems. Nevertheless, lyophilized microarrays provided a proper detection of pathogen DNA. Standard regression curves built on serial DNA dilutions showed good linearity for all test systems (Table 7, Figure S5) with highly significant negative correlation between $C_{t}$ values and DNA concentration over the range used $\left(R^{2}>0.97\right)$. The lowest DNA concentration providing a $C_{t}$ value below threshold value $\left(C_{t}=35\right)$, were 95 (Asol4), 5.8 (Aalt1), 22 (Rsol4), 84 (Ccoc), 2 (Sss), and 4 (Fus) ng/mL that corresponded to 95, $5.8,22,84,2$, and 4 pg of DNA.

Table 6. Comparison of working efficiency of freshly prepared and lyophilized microarrays for detection and identification of fungal pathogens of potato.

\begin{tabular}{ccccc}
\hline Test & \multicolumn{2}{c}{ Freshly Prepared } & Lyophilized \\
\hline System $^{\mathbf{1}}$ & $\left.\mathbf{C}_{\mathbf{t}} \mathbf{( M} \pm \mathbf{S E}\right)$ & Fluorescence Level at the End of Analysis & $\left.\mathbf{C}_{\mathbf{t}} \mathbf{( M} \pm \mathbf{S E}\right)$ & Fluorescence Level at the End of Analysis \\
\hline Asol4 & $24.06 \pm 0.42$ & 3000 & $26.50 \pm 2.25$ & 1300 \\
Aalt1 & $25.70 \pm 0.05$ & 5700 & $24.56 \pm 0.42$ & 1400 \\
Rsol4 & $19.54 \pm 0.38$ & 5600 & $18.80 \pm 0.25$ & 1900 \\
Ccoc & $27.25 \pm 0.39$ & 3500 & $26.61 \pm 1.02$ & 980 \\
Fus & $25.40 \pm 0.25$ & 7500 & $24.49 \pm 0.88$ & 1500 \\
Sss & $26.79 \pm 0.03$ & 6800 & $26.56 \pm 0.09$ & 2200 \\
\hline
\end{tabular}

${ }^{1}$ Test systems designations: Asol4, Alternaria solani; Aalt1, A. alternata; Rsol4, Rhizoctonia solani; Ccoc, Colletotrichum coccodes; Sss, Spongospora subterranea; Fus, Fusarium spp.

Table 7. Performance of lyophilized diagnostic systems for serial dilutions of DNA of target species.

\begin{tabular}{|c|c|c|c|c|c|}
\hline Target Species & $\begin{array}{l}\text { DNA Concentration, } \\
\mu \mathrm{g} / \mathrm{mL}\end{array}$ & $\begin{array}{l}\text { Threshold } \\
\text { Cycle }(\mathrm{Ct})^{1}\end{array}$ & Target Species & $\begin{array}{l}\text { DNA Concentration, } \\
\mu \mathrm{g} / \mathrm{mL}\end{array}$ & $\begin{array}{l}\text { Threshold } \\
\text { Cycle (Ct) }\end{array}$ \\
\hline \multirow{5}{*}{ Alternaria solani } & 136.4 & $26.50 \pm 0.24$ & \multirow{5}{*}{ Alternaria alternata } & 43.5 & $20.64 \pm 0.39$ \\
\hline & 13.64 & $29.23 \pm 0.22$ & & 4.35 & $23.74 \pm 0.32$ \\
\hline & 1.364 & $32.87 \pm 0.41$ & & 0.435 & $27.73 \pm 0.38$ \\
\hline & 0.1364 & $34.08 \pm 0.86$ & & 0.0435 & $31.85 \pm 0.59$ \\
\hline & 0.01364 & $37.18 \pm 0.96$ & & 0.00435 & $35.51 \pm 0.86$ \\
\hline \multirow{4}{*}{ Rhizoctonia solani } & 18.32 & $18.40 \pm 0.40$ & \multirow{4}{*}{ Colletotrichum coccodes } & 19.3 & $24.47 \pm 0.38$ \\
\hline & 1.832 & $24.41 \pm 0.70$ & & 1.93 & $29.84 \pm 0.47$ \\
\hline & 0.1832 & $31.57 \pm 0.98$ & & 0.193 & $34.09 \pm 0.55$ \\
\hline & 0.01832 & $34.33 \pm 1.14$ & & 0.0193 & $37.10 \pm 0.85$ \\
\hline \multirow{5}{*}{ Fusarium sp. } & 44.6 & $22.42 \pm 0.24$ & \multirow{5}{*}{ Spongospora subterranea } & 23.2 & $23.35 \pm 0.35$ \\
\hline & 4.46 & $24.50 \pm 0.33$ & & 2.32 & $26.46 \pm 0.27$ \\
\hline & 0.446 & $28.54 \pm 0.48$ & & 0.232 & $29.43 \pm 0.39$ \\
\hline & 0.0446 & $31.73 \pm 0.64$ & & 0.0232 & $32.73 \pm 0.62$ \\
\hline & 0.00446 & $34.73 \pm 0.62$ & & 0.00232 & $35.37 \pm 0.76$ \\
\hline
\end{tabular}

${ }^{1}$ Data are shown in the form of $\mathrm{M} \pm \mathrm{SE}$, where $\mathrm{M}$ is a mean value and $\mathrm{SE}$ is the standard error calculated for three replications.

\subsection{Validation of Test Systems with Field Samples}

Results of examination of field samples with visible manifestations of target fungal pathogens are shown in Table 8. For majority of samples, results of the microscopic and PCR examination were similar. For T6 sample, microscopic examination revealed the presence of three pathogens, while PCR analysis on a microarray showed additionally the presence of $C$. coccodes. Analysis of L6 sample did 
not reveal $A$. solani, though microscopic examination confirmed the presence of single conidia of this pathogen. In both cases, the difference between the obtained results may be explained by a low limit presence of pathogen. Some samples (T4, T5, L7, S5, S13) did not show their actual presence of target pathogens under microscope and by PCR analysis, though having some manifestations of infection. That might be explained by the wrong initial diagnosis (presence of common scab instead of powdery scab in T4 and T5), or confusion with some abiotic factors or bacterial infection (L7, S5, S13).

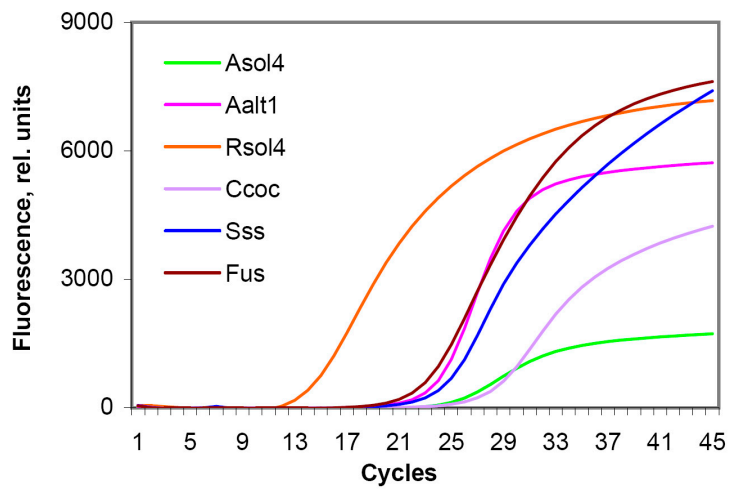

(a)

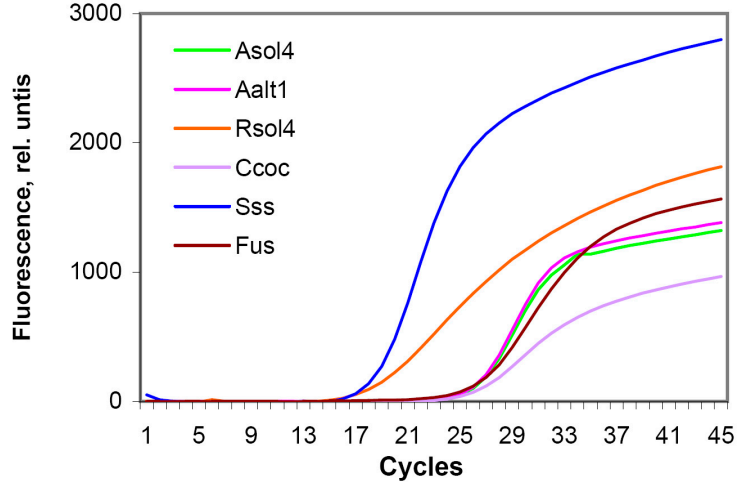

(b)

Figure 4. Parallel detection of target potato pathogens using (a) freshly prepared and (b) lyophilized test systems applied onto 48-well Si microarrays. Test systems designations: Asol4, Alternaria solani; Aalt1, A. alternata; Rsol4, Rhizoctonia solani; Ccoc, Colletotrichum coccodes; Sss, Spongospora subterranea; Fus, Fusarium spp.

In the most cases, $C_{t}$ values obtained for target pathogens did not exceed 35 , so were considered as positive results. Note that $C_{t}$ values for the T6 and S11 (34.3 for A. alternata and 35.0 for C. coccodes, respectively) were very close or equal to the threshold value; though still being considered as being positive, they indicate a low infection load of the corresponding pathogens. In the case of L5, $\mathrm{C}_{\mathrm{t}}=36.1$ for $A$. alternata that may be caused by either too low presence of the pathogen, or any nonspecific reaction. In such situation, no conclusion about the presence of a target pathogen can be made, and the result is considered to be negative. Since microscopic examination showed the presence of this fungus in the sample, we consider that the most possible reason of the obtained result is very low level of infection that is quite possible in the case of secondary colonization of necrotic lesions caused by $A$. solani with $A$. alternata [44].

Table 8. Validation of a diagnostic efficiency of a qPCR microarray for detection of fungal pathogens of potato using field samples of potato leaves and tubers.

\begin{tabular}{|c|c|c|c|c|}
\hline Sample No. ${ }^{1}$ & Origin $^{2}$ & Visual Symptoms & $\begin{array}{l}\text { Microscopic } \\
\text { Examination }^{3}\end{array}$ & $\begin{array}{l}\text { Real-Time } \\
\text { PCR Analysis }\end{array}$ \\
\hline $\mathrm{T} 1$ & Leningrad region, Russia & Dry and dark surface lesions & $\begin{array}{l}\text { Aalt } \\
\text { Sss }\end{array}$ & $\begin{array}{l}\text { Aalt (25.2) } \\
\text { Sss (30.4) }\end{array}$ \\
\hline $\mathrm{T} 2$ & Leningrad region, Russia & Dry and dark surface lesions & Sss & Sss (31.5) \\
\hline $\mathrm{T} 3$ & Moscow region, Russia (Red Scarlett) & Black scurf (Rhizoctonia solani) & Rsol & Rsol (25.6) \\
\hline $\mathrm{T} 4$ & Tambov region, Russia & $\begin{array}{l}\text { Superficial scabs (powdery scab } \\
\text { suspected) }\end{array}$ & $\begin{array}{l}\text { No spore balls of } \\
\text { S. subterranea }\end{array}$ & - \\
\hline T5 & Omsk region, Russia & $\begin{array}{l}\text { Superficial scabs (powdery or common } \\
\text { scab suspected) }\end{array}$ & $\begin{array}{l}\text { No spore balls of } \\
\text { S. subterranea }\end{array}$ & - \\
\hline T6 & Unknown (bought in a supermarket) & $\begin{array}{l}\text { Black scurf, superficial scabs and dry } \\
\text { lesions }\end{array}$ & $\begin{array}{l}\text { Sss } \\
\text { Rsol } \\
\text { Aalt (single conidia) }\end{array}$ & $\begin{array}{l}\text { Sss (26.7) } \\
\text { Ccoc (29.2) } \\
\text { Rsol (21.4) } \\
\text { Aalt (34.3) }\end{array}$ \\
\hline $\mathrm{T} 7$ & Leningrad region (Red Scarlett) & Black scurf, superficial dry lesions & $\begin{array}{l}\text { Rsol } \\
\text { Aalt } \\
\text { Ccoc }\end{array}$ & $\begin{array}{l}\text { Ccoc (31.4) } \\
\text { Aalt (27.3) } \\
\text { Rsol (20.4) }\end{array}$ \\
\hline
\end{tabular}


Table 8. Cont.

\begin{tabular}{|c|c|c|c|c|}
\hline Sample No. ${ }^{1}$ & Origin $^{2}$ & Visual Symptoms & $\begin{array}{l}\text { Microscopic } \\
\text { Examination }^{3}\end{array}$ & $\begin{array}{l}\text { Real-Time } \\
\text { PCR Analysis }\end{array}$ \\
\hline T8 & Moscow region (Red Scarlett) & Dry rot & Fus (F. oxysporum) & Fus (17.6) \\
\hline T9 & Moscow region (Red Scarlett) & Dry rot & Fus (F. oxysporum) & Fus (21.4) \\
\hline L1 & Republic of Tatarstan, Russia & Brown spot disease & Aalt & Aalt (29.4) \\
\hline L2 & $\begin{array}{l}\text { Republic of Kabardino-Balkaria, } \\
\text { Russia }^{5}\end{array}$ & Brown spot disease & Aalt & Aalt (33.7) \\
\hline L3 & Moscow region, Russia (Red Scarlett) & Brown spot disease & Aalt & Aalt (27.7) \\
\hline $\mathrm{L} 4$ & Moscow region, Russia (Alpha) & Early blight/brown spot & Aalt & Aalt (34.1) \\
\hline L5 & Moscow region, Russia (Udacha) & Early blight/brown spot & $\begin{array}{l}\text { Asol } \\
\text { Aalt (single conidia) }\end{array}$ & $\begin{array}{l}\text { Asol (26.8) } \\
\text { Aalt (36.1) }\end{array}$ \\
\hline L6 & Tambov region (Alouette) & Early blight/brown spot & $\begin{array}{l}\text { Asol (single conidia) } \\
\text { Aalt }\end{array}$ & Aalt (28.3) \\
\hline L7 & Tambov region (Alouette) & Early blight/brown spot & - & - \\
\hline L8 & Tambov region (Alouette) & Early blight/brown spot & Aalt & Aalt (32.5) \\
\hline S1 & Moscow region, Russia (Red Scarlett) & Stem canker $(R$ solani $)$ & Rsol & Rsol \\
\hline S2 & Moscow region, Russia (Red Scarlett) & Black dot (C. coccodes) & Ccoc & C coc (32.1) \\
\hline S3 & Tyumen region, Russia (Red Scarlett) & Stem canker & Rsol & Rsol (30.1) \\
\hline S4 & Tyumen region, Russia (Evolution) & Stem canker & Rsol & Rsol (26.1) \\
\hline S5 & Tyumen region, Russia (Red Scarlett) & Black dot suspected & - & - \\
\hline S6 & Sverdlovsk region, Russia (Rozara) & Stem canker, black dot & Rsol, Ccoc, & $\begin{array}{l}\text { Rsol (32.0) } \\
\text { Ccoc (30.0) }\end{array}$ \\
\hline S7 & Sverdlovsk region, Russia (Rozara) & Stem canker, black dot (suspected) & $\begin{array}{l}\text { Rsol } \\
\text { Ccoc }\end{array}$ & $\begin{array}{l}\text { Rsol (33.2) } \\
\text { Ccoc (34.0) }\end{array}$ \\
\hline S8 & Sverdlovsk region, Russia (Gala) & Stem canker & Rsol & Rsol (24.3) \\
\hline S9 & Kurgan region, Russia (Rozara) & Stem canker & Rsol & Rsol (34.0) \\
\hline $\mathrm{S} 10$ & $\begin{array}{l}\text { Chelyabinsk region, } \\
\text { Russia (Red Scarlett) }\end{array}$ & Stem canker & Rsol & Rsol (34.2) \\
\hline S11 & $\begin{array}{l}\text { Chelyabinsk region, } \\
\text { Russia (Red Scarlett) }\end{array}$ & Black dot & Ccoc & C $\operatorname{coc}(35.0)$ \\
\hline S12 & $\begin{array}{l}\text { Chelyabinsk region, } \\
\text { Russia (Red Scarlett) }\end{array}$ & Stem canker & Rsol & Rsol (32.7) \\
\hline S13 & $\begin{array}{l}\text { Chelyabinsk region, } \\
\text { Russia (Red Scarlett) }\end{array}$ & Stem canker suspected & - & - \\
\hline
\end{tabular}

$1 \mathrm{~T}, \mathrm{~L}$, and S indicate potato tubers, leaves, and stems, respectively. ${ }^{2}$ Potato cultivar is indicated in brackets (if known). 3 Pathogen designations: Asol, Alternaria solani; Aalt, A. alternata; Rsol, Rhizoctonia solani; Ccoc, Colletotrichum coccodes; Sss, Spongospora subterranea; Fus, Fusarium spp. ${ }^{4} \mathrm{C}_{\mathrm{t}}$ values are shown in brackets.

5 The sample was collected from a tomato plant.

\section{Discussion}

Being uncontrolled, fungal diseases of potato may have devastating effects on crop yield resulting in great economic losses. Like many soil-borne diseases, they can be symptomless during early infection stages and have long latent periods that complicate timely diagnostics. In addition, many fungal pathogens have similar symptoms and may be confused between themselves or with manifestations of various abiotic stresses. At the same time, early accurate detection and identification of fungal pathogens is the milestone of plant pathology, which provides an essential prerequisite to efficient implementation of disease management strategies. Another important moment are the benefits of early diagnostics performed on-site or in field laboratories, since it allows growers to make timely decisions concerning disease management strategies, to reduce impact of the disease, and, finally, save time and money.

In this study species-specific (genus-specific for Fusarium spp.) primers and probes were designed for detection of six important fungal pathogens of potato. The developed species-specific test systems were proved to be specific for the corresponding target species and did not show any cross-reactions with non-target fungi included into the study. At the same time, in the case of the test system for S. subterranea detection, some additional tests are desirable with some phylogenetically close plasmodiophorid species to confirm a high specificity of this assay. Since plasmodiophorids are obligate intracellular parasites, it is difficult to find them in the form of pure culture; nevertheless, we plan to do this study in the future. 
The Fusarium genus-specific assay proved to be highly specific, detecting all of the reference Fusarium strains, with no cross-reaction with other fungal strains. The limitation of this assay is that the Fusarium genus includes both pathogenic and non-pathogenic species, i.e., a positive result may indicate the presence of either harmful, or harmless species. At the same time, while other target genera include mainly 1-2 species, which are pathogenic for potato, this genus includes at least 5-6 main species infecting potato (F. sambucinum, F. oxusporum, F. avenaceum, F. solani, F. equiseti, and F. culmorum) and also several less important species [45-47]. Therefore, use of species-specific assays for all Fusarium species pathogenic for potato may significantly reduce the number of samples, which can be tested per one microarray, and, therefore, increase the cost of analysis. We consider that the developed genus-specific test system can be used for primary on-site diagnostics, while the species-specific identification of Fusarium fungi (if they will be revealed) can be performed as the second stage. For this purpose, we plan to develop species-specific test systems for the main Fusarium pathogens, which then may be used not only for potato samples, but also for other vegetable crops and cereals, which significantly suffer from this fungal genus.

Standard regression curves demonstrated that the selected primer sets were highly accurate over the linear range of at least four orders of DNA content. In addition, all test systems showed good reproducibility (standard errors for $C_{t}$ values did not exceed $0.7 \%$ ).

Sensitivity is also an important characteristic of diagnostic test systems. In the case of $S$. subterranea and A. alternata, detection limits were 0.6 and $3.3 \mathrm{pg}$ of DNA per reaction, respectively, that is close to the sensitivity of assays developed by other researchers $[48,49]$, though is worse than some other published data (0.1 pg for both pathogens [50,51]). For Fusarium spp., a number of publications describe the development of diagnostic assays for single species, though only few describe genus-specific primer sets [52-54] or test systems detecting at least several Fusarium species causing dry rot of potato [55]. Sensitivity of the developed test system (1.7 pg of DNA) is inferior to that of some mentioned assays (0.2 [52] and 0.5 [55] pg of DNA or even one DNA copy per reaction [54]), though still remains at good diagnostic level. The other three test systems showed higher detection limits: 18, 37, and 43,5 pg of DNA for $R$ solani, C. coccodes, and A. solani, respectively. These values are higher than those for laboratory real-time assays developed by other authors (0.1-1 pg for A. solani [51,56], 2-20 pg for C. coccodes [57,58], and 0.1-2 pg for $R$ solani [59-61]), but still provide an adequate level of detection of target pathogens. Note that in our case, a primer selection process had several limiting conditions, the most important of which were the amplicon size and the efficient work of the developed assay at $\mathrm{T}_{\mathrm{a}}=60^{\circ} \mathrm{C}$. These conditions limited the range of appropriate variants, so in some cases we were not able to achieve high sensitivity of chosen primers; nevertheless, they still have quite good efficiency for the on-site testing of infected plants.

Parallel testing of the same DNA samples of target pathogens on freshly prepared and freeze-dried microarrays demonstrated that immobilization and freeze-drying of PCR mix components in reaction wells reduced the maximum fluorescence levels 2.5-3-fold (Table 7), which was expected; this effect might be caused by the immobilized state of freeze-dried DNA polymerase and oligonucleotides resulting in their conformational changes; in addition, the quenching effect may also appear due to a crowding of fluorescently labeled probe molecules. Nevertheless, it did not significantly affect $C_{t}$ values, i.e., the procedure of preparation of preserved microarrays did not provide a significant negative effect on the working efficiency of the test systems. The further sensitivity test performed on the preserved microarrays showed the detection limits within the range of 2-6 pg of DNA for S. subterranea, A. alternata, and Fusarium spp. and 22-95 pg of DNA for $R$ solani, C. coccodes, and A. solani that was higher than in freshly prepared microarrays, but is still enough for a satisfactory detection level. Diagnostic efficiency of microarrays was successfully validated using infected field samples of potato plants and a parallel morphological identification of pathogens.

Thus, in this study we have successfully developed and validated test systems for diagnostics of six economically important fungal pathogens of potato intended for the use in preserved disposable real-time PCR microarrays. Such diagnostic microarrays provide simultaneous analysis of five samples 
for the presence of six pathogens. Due to small reaction volume $(1 \mu \mathrm{L})$ and special technology for stabilization and freeze-drying of PCR mix components, the number of required procedures is significantly reduced, and the total time of analysis (including DNA extraction) takes only $\sim 1.5 \mathrm{~h}$. In addition, the use of preserved microarrays and automated data interpretation significantly simplifies the procedure and does not require highly-qualified personnel. This fact, together with a long shelf life of preserved microarrays at room temperature, provides an excellent suitability of microarrays for use by unskilled persons under conditions of field laboratories.

Despite obvious advantages of the proposed approach, there are also some issues that should be addressed in future. First, since all test systems arranged on the same microarray should work under the same amplification conditions, we developed original primers with similar optimal working temperatures and regimes. Due to this limitation, some of the developed primers showed increased detection limits. Though they are still suitable for the use in situation, when a potato grower finds some lesions on potato plants or tubers and wants to determine if there is a disease manifestation, which requires some control measures, their use for diagnostics of hidden diseases requires better sensitivity, so their further improvement should be done. Second, more fungal strains of target and non-target species should be tested to ensure specificity. Third, validation of the approach should be continued for a large number of infested field samples.

Among other possible directions of the further work, one should mention the development of test systems for detection of other fungal pathogens of potato, such as S. endobioticum, Phoma spp., Pythium spp. with their further combining with the earlier developed ones in the same microarrays. In addition, many of fungal pathogens of potato belong to soil-borne pathogens. They may develop special structures, such as spores and melanized hyphae to survive in soil for many years, so the proper detection of their presence in soil (especially quarantine species) is also very important for timely decisions regarding early-stage treatments or pre-plant assessments of the fields. Therefore, there is a need to develop an efficient protocol for detection of target pathogens in soil samples.

Due to simplicity of the approach we have developed, it can be used for pathogen detection by potato growers themselves without need to send samples to a diagnostic laboratory that could be quite away from the source. Flexibility of the microarray matrix topology and standard amplification conditions for all primer sets provide the possibility to combine test systems for various pathogens (fungi, bacteria, nematodes) depending on epidemiological situation at the point of use and on the needs of the customer (diagnostics of storage diseases, soil-borne pathogens, leaf infections, etc.). The multiplex mode of detection makes it possible to reveal combined infections and to perform high-throughput monitoring of potato infections on the basis of regional plant protection services. Due to above-mentioned reasons, the developed approach has a great potential for on-site use and will contribute to current diagnostic pipeline, as well as monitoring of potato pathogens.

Supplementary Materials: The following are available online at http:/ www.mdpi.com/2079-6374/8/4/129/s1, Figure S1. Alignment of DNA sequences in the regions used for primer design for Alternaria solani, Alternaria alternata, and Rhizoctonia solani; Figure S2. Alignment of DNA sequences in the regions used for primer design for Colletotrichum coccodes and Spongospora subterranea; Figure S3. Alignment of DNA sequences in the regions used for genus-specific primer design for Fusarium spp.; Figure S4. Examples of fluorescent curves illustrating specificity of the test systems developed for detection and identification of Alternaria solani, A. alternata, Rhizoctonia solani, Colletotrichum coccodes, S. subterranea, and Fusarium spp.; Figure S5. Standard regression curves of a serial dilution of DNA from the target potato pathogens obtained for freeze-dried microarrays. Table S1. Effect of annealing temperature on the efficiency of test systems developed for detection of target fungal pathogens of potato.

Author Contributions: Conceptualization: A.G. and V.D.; methodology: A.G. and M.N.; investigation: M.N., N.G., and M.K.; validation: M.N., K.D., and I.G.; resources: K.D., I.G., M.K., and M.P.; formal analysis: N.S. and M.N.; writing—original draft preparation: N.S.; writing—review and editing: V.D. and A.G.; supervision: A.G.

Funding: This research was financially supported by the Russian Science Foundation (project no. 16-16-04109) excepting the technology for preparation of preserved microarrays, which has been developed independently of this study, and the collection of field samples, which has been performed within the framework of the Governmental Program "Development of potato breeding and seed production in Russian Federation" (Block 8, project "Monitoring and study of a potato late blight in Russia: mapping of regions by the threat of possible epidemics and the costs of protective fungicide treatments"). 
Acknowledgments: The authors are grateful to the State Collection of Plant Pathogenic Microorganisms, Indicator Plants and Differential Cultivars of the All-Russian Research Institute of Phytopathology for provided strains of fungal potato pathogens.

Conflicts of Interest: Authors declare no conflict of interest.

\section{References}

1. World Potato Statistics. Available online: https://www.potatopro.com/world/potato-statistics (accessed on 10 October 2018).

2. Moore, D.; Robson, G.D.; Trinci, A.P. 21st Century Guidebook to Fungi; Cambridge University Press: Cambridge, UK, 2011; pp. 368-369. ISBN 978-1107419711.

3. Oerke, E.-C. Crop losses to pests. J. Agric. Sci. 2006, 144, 31-43. [CrossRef]

4. Haverkort, A.; Struik, P.; Visser, R.; Jacobsen, E. Applied biotechnology to combat late blight in potato caused by Phytophthora Infestans. Potato Res. 2009, 52, 249-264. [CrossRef]

5. Tsror, L. Biology, epidemiology and management of Rhizoctonia solani on potato. J. Phytopathol. 2010, 110, 111-118. [CrossRef]

6. Thangavel, T.; Tegg, R.S.; Wilson, C.R. Monitoring Spongospora subterranea development in potato roots reveals distinct infection patterns and enables efficient assessment of disease control methods. PLOS ONE 2015, 10, e0137647. [CrossRef] [PubMed]

7. Baayen, R.; Cochius, G.; Hendriks, H.; Meffert, J.; Bakker, J.; Bekker, M.; van den Boogert, P.; Stachewicz, H.; van Leeuwen, G. History of potato wart disease in Europe-A proposal for harmonisation in defining pathotypes. Eur. J. Plant Pathol. 2006, 116, 21-31. [CrossRef]

8. Abbas, M.F.; Naz, F.; Irshad, G. Important fungal diseases of potato and their management-A brief review. Mycopath 2013, 11, 45-50.

9. Tsror, L.; Erlich, O.; Hazanovsky, M. Effect of Colletotrichum coccodes on potato yield, tuber quality, and stem colonization during spring and autumn. Plant Dis. 1999, 83, 561-565. [CrossRef]

10. Bojanowski, A.; Avis, T.J.; Pelletier, S.; Tweddell, R.J. Management of potato dry rot. Postharvest Boil. Technol. 2013, 84, 99-109. [CrossRef]

11. De Haan, E.G.; Van Den Bovenkamp, G. Improved diagnosis of powdery scab (Spongospora subterranea f.sp. subterranea) symptoms on potato tubers (Solarium tuberosum L.). Potato Res. 2005, 48, 1-14. [CrossRef]

12. Turkensteen, J.; Spoelder, J.; Mulder, A. Will the real Alternaria stand up please: Experiences with Alternaria-like diseases on potatoes during the 2009 season in the Netherlands. PPO-Spec. Rep. 2010, 14, 165-170.

13. Martinelli, F.; Scalenghe, R.; Davino, S.; Panno, S.; Scuderi, G.; Ruisi, P.; Villa, P.; Stroppiana, D.; Boschetti, M.; Goulart, L.R.; et al. Advanced methods of plant disease detection. A review. Agron. Sustain. Dev. 2015, 35, 1-25. [CrossRef]

14. Bonantz, P.J.M.; Shoen, C.D.; Szemes, M.; Speksnijder, A.; Klerks, M.M.; van den Boogert, P.H.J.F.; Waalwijk, C.; van der Wolf, J.M.; Zijltra, C. From single to multiple detection of plant pathogens: PUMA, a new concept of multiplex detection using microarrays. Phytopathol. Pol. 2005, 35, 29-47.

15. Chen, W.; Djama, Z.R.; Coffey, M.D.; Martin, F.N.; Bilodeau, G.J.; Radmer, L.; Denton, G.; Lévesque, C.A. Membrane-based oligonucleotide array developed from multiple markers for the detection of many Phytophthora species. Phytopathology 2013, 103, 43-54. [CrossRef] [PubMed]

16. Zhang, N.; McCarthy, M.L.; Smart, C.D. A macroarray system for the detection of fungal and oomycete pathogens of solanaceous crops. Plant Dis. 2008, 92, 953-960. [CrossRef]

17. Vreeburg, R.A.; Bergsma-Vlami, M.; Bollema, R.M.; Haan, E.G.; Kooman-Gersmann, M.; Smits-Mastebroek, L.; Tameling, W.I.; Tjou-Tam-Sin, N.N.; Vossenberg, B.T.; Janse, J.D. Performance of real-time PCR and immunofluorescence for the detection of Clavibacter michiganensis subsp. sepedonicus and Ralstonia solanacearum in potato tubers in routine testing. EPPO Bull. 2016, 46, 112-121. [CrossRef]

18. Pastuszewska, T.; Lewosz, J.; Sadoch, Z. Application of IFAs and PCR for Clavibacter michiganensis subsp. sepedonicus detection in potato plants during the growing season. Phytopathol. Pol. 2005, 35, 95-102.

19. Elad, Y.; Pertot, I. Climate change impacts on plant pathogens and plant diseases. J. Crop. Improv. 2014, 28, 99-139. [CrossRef] 
20. Garrett, K.A.; Dendy, S.P.; Frank, E.E.; Rouse, M.N.; Travers, S.E. Climate change effects on plant disease: Genomes to ecosystems. Annu. Rev. Phytopathol. 2006, 44, 489-509. [CrossRef] [PubMed]

21. Sanati Nezhad, A. Future of portable devices for plant pathogen diagnosis. Lab Chip 2014, 14, $2887-2904$. [CrossRef]

22. Mirmajlessi, S.M.; Loit, E.; Mand, M.; Mansouripour, S.M. Real-time PCR applied to study on plant pathogens: Potential applications in diagnosis-A review. Plant Prot. Sci. 2015, 51, 177-190. [CrossRef]

23. Safenkova, I.V.; Pankratova, G.K.; Zaitsev, I.A.; Varitsev, Y.A.; Vengerov, Y.Y.; Zherdev, A.V.; Dzantiev, B.B. Multiarray on a test strip (MATS): Rapid multiplex immunodetection of priority potato pathogens. Anal. Bioanal. Chem. 2016, 408, 6009-6017. [CrossRef] [PubMed]

24. DeShields, J.B.; Bomberger, R.A.; Woodhall, J.W.; Wheeler, D.L.; Moroz, N.; Johnson, D.A.; Tanaka, K. On-site molecular detection of soil-borne phytopathogens using a portable real-time PCR system. J. Vis. Exp. 2018, 132, e56891. [CrossRef] [PubMed]

25. Khiyami, M.A.; Almoammar, H.; Awad, Y.M.; Alghuthaymi, M.A.; Abd-Elsalam, K.A. Plant pathogen nanodiagnostic techniques: Forthcoming changes? Biotechnol. Biotechnol. Equip. 2014, 28, 775-785. [CrossRef] [PubMed]

26. Huanca-Mamani, W.; Salvatierra Martínez, R.; Sepúlveda-Chavera, G. A fast and efficient method for total DNA extraction from soil filamentous fungi. Idesia 2014, 32, 75-78. [CrossRef]

27. Grund, E.; Darissa, O.; Adam, G. Application of FTA ${ }^{\circledR}$ cards to sample microbial plant pathogens for PCR and RT-PCR. J. Phytopathol. 2010, 158, 750-757. [CrossRef]

28. Le, D.T.; Vu, N.T. Progress of loop-mediated isothermal amplification technique in molecular diagnosis of plant diseases. Appl. Boil. Chem. 2017, 60, 169-180. [CrossRef]

29. Khater, M.; Escosura-Muñiza, A.; Merkoçi, A. Biosensors for plant pathogen detection. Biosens. Bioelectron. 2017, 93, 72-86. [CrossRef] [PubMed]

30. Fang, Y.; Ramasamy, R.P. Current and prospective methods for plant disease detection. Biosensors 2015, 4, 537-561. [CrossRef] [PubMed]

31. Ahmad, F.; Hashsham, S.A. Miniaturized nucleic acid amplification systems for rapid and point-of-care diagnostics: A review. Anal. Chim. Acta 2012, 733, 1-15. [CrossRef] [PubMed]

32. Ryazantsev, D.; Zavriev, S. An efficient diagnostic method for the identification of potato viral pathogens. Mol. Boil. 2009, 43, 515-523. [CrossRef]

33. Cating, R.A.; Funke, C.N.; Kaur, N.; Hamm, P.B.; Frost, K.E. A multiplex reverse transcription (RT) high-fidelity PCR protocol for the detection of six viruses that cause potato tuber necrosis. Am. J. Potato Res. 2015, 92, 536-540. [CrossRef]

34. Ranjan, R.K.; Singh, D.; Baranwal, V.K. Simultaneous detection of brown rot- and soft rot-causing bacterial pathogens from potato tubers through multiplex PCR. Curr. Microbiol. 2016, 73, 652-659. [CrossRef] [PubMed]

35. Nikitin, M.; Statsyuk, N.; Frantsuzov, P.; Dzhavakhiya, V.; Golikov, A. Matrix approach to the simultaneous detection of multiple potato pathogens by real-time PCR. J. Appl. Microbiol. 2018, 124, 797-809. [CrossRef] [PubMed]

36. Nikitin, M.M.; Statsyuk, N.V.; Frantsuzov, P.A.; Pridannikov, M.V.; Golikov, A.G. Rapid and simple detection of two potato cyst nematode species by real-time multiplex PCR using preserved microarray-based test systems. Russ. J. Nematol. 2017, 25, 51-60.

37. Deych, K.O.; Pridannikov, M.V.; Nikitin, M.M.; Statsyuk, N.V.; Dzhavakhiya, V.G.; Golikov, A.G. Simultaneous detection of three plant parasitic nematode species from the genus Ditylenchus using a real-time qPCR matrix-based technology. Russ. J. Nematol.. accepted.

38. Qu, X.; Christ, B.J. Single cystosorus isolate and restriction fragment length polymorphism characterization of the obligate biotroph Spongospora subterranea f. sp. subterranea. Phytopathology 2006, 96, 1157-1163. [CrossRef]

39. GenBank Geneti Sequence Database. Available online: http://www.ncbi.nlm.nih.gov/genbank/ (accessed on 10 December 2018).

40. OLIGO Primer Analysis Software. Available online: http:/ /www.oligo.net/ (accessed on 10 December 2018).

41. Basic Local Alignment Search Tool. Available online: https://blast.ncbi.nlm.nih.gov/ (accessed on 10 December 2018).

42. State Standard R 55329-2012. Seed Potatoes. Acceptance Rules and Methods of Analysis; Standartinform: Moscow, Russia, 2013; pp. 8-10. (In Russian) 
43. Pidoplichko, N.M. Parasitic Fungi of Agricultural Crops. Identification Guide; Naukova Dumka: Kiev, Ukraine, 1977; Volume 2. (In Russian)

44. Kokaeva, L.Y.; Belosokhov, A.F.; Doeva, L.Y.; Skolotneva, E.S.; Elansky, S.N. Distribution of Alternaria species on blighted potato and tomato leaves in Russia. J. Plant Dis. Prot. 2018, 125, 205-212. [CrossRef]

45. Du, M.; Ren, X.; Sun, Q.; Wang, Y.; Zhang, R. Characterization of Fusarium spp. causing potato dry rot in China and susceptibility evaluation of Chinese potato germplasm to the pathogen. Potato Res. 2012, 55, 175-184. [CrossRef]

46. Stefańczyk, E.; Sobkowiak, S.; Brylińska, M.; Śliwka, J. Diversity of Fusarium spp. associated with dry rot of potato tubers in Poland. Eur. J. Plant Pathol. 2016, 145, 871-884. [CrossRef]

47. Gachango, E.; Hanson, L.E.; Rojas, A.; Hao, J.J.; Kirk, W.W. Fusarium spp. causing dry rot of seed potato tubers in Michigan and their sensitivity to fungicides. Plant Dis. 2012, 96, 1767-1774. [CrossRef]

48. Konstantinova, P.; Bonants, P.J.M.; van Gent-Pelzer, M.P.E.; van der Zouwen, P.; van den Bulk, R. Development of specific primers for detection and identification of Alternaria spp. in carrot material by PCR and comparison with blotter and plating assays. Mycol. Res. 2002, 106, 23-33. [CrossRef]

49. Van de Graaf, P.; Lees, A.K.; Cullen, D.W.; Duncan, J.M. Detection and quantification of Spongospora subterranea in soil, water and plant tissue samples using real-time PCR. Eur. J. Plant Pathol. 2003, 109, 589-597. [CrossRef]

50. Qu, X.; Wanner, L.; Christ, B. Multiplex real-time PCR (TaqMan) assay for the simultaneous detection and discrimination of potato powdery and common scab diseases and pathogens. J. Appl. Microbiol. 2011, 110, 769-777. [CrossRef] [PubMed]

51. Leiminger, J.; Bäßler, E.; Knappe, C.; Bahnweg, G.; Hausladen, H. Quantification of disease progression of Alternaria spp. on potato using real-time PCR. Eur. J. Plant Pathol. 2015, 141, 295-309. [CrossRef]

52. Grube, S.; Schönling, J.; Prange, A. Evaluation of a triplex real-time PCR system to detect the plant-pathogenic molds Alternaria spp., Fusarium spp. and C. Purpurea. J. Microbiol. Methods 2015, 119, 180-188. [CrossRef] [PubMed]

53. Graça, M.G.; van der Heijden, I.M.; Perdigão, L.; Taira, C.; Costa, S.F.; Levin, A.S. Evaluation of two methods for direct detection of Fusarium spp. in water. J. Microbiol. Methods 2016, 123, 39-43. [CrossRef] [PubMed]

54. Muraosa, Y.; Schreiber, A.Z.; Trabasso, P.; Matsuzawa, T.; Taguchi, H.; Moretti, M.L.; Mikami, Y.; Kamei, K. Development of cycling probe-based real-time PCR system to detect Fusarium species and Fusarium solani species complex (FSSC). Int. J. Med Microbiol. 2014, 304, 505-511. [CrossRef]

55. Atallah, Z.K.; Stevenson, W.R. A methodology to detect and quantify five pathogens causing potato tuber decay using real-time quantitative polymerase chain reaction. Phytopathology 2006, 96, 1037-1045. [CrossRef]

56. Edin, E. Species specific primers for identification of Alternaria solani, in combination with analysis of the F129L substitution associates with loss of sensitivity toward strobilurins. Crop. Prot. 2012, 38, 72-73. [CrossRef]

57. Cullen, D.W.; Lees, A.K.; Toth, I.K.; Duncan, J.M. Detection of Colletotrichum coccodes from soil and potato tubers by conventional and quantitative real-time PCR. Plant Pathol. 2002, 51, 281-292. [CrossRef]

58. Dauch, A.L.; Watson, A.K.; Seguin, P.; Jabaji-Hare, S.H. Real-time PCR quantification of Colletotrichum coccodes DNA in soils from bioherbicide field-release assays, with normalization for PCR inhibition. Can. J. Plant Pathol. 2006, 28, 42-51. [CrossRef]

59. Dubey, S.C.; Tripathi, A.; Upadhyay, B.K.; Kumar, A. Development of conventional and real time PCR assay for detection and quantification of Rhizoctonia solani infecting pulse crops. Biologia 2016, 71, 133-138. [CrossRef]

60. Woodhall, J.W.; Adams, I.P.; Peters, J.C.; Harper, G.; Boonham, N. A new quantitative real-time PCR assay for Rhizoctonia solani AG3-PT and the detection of AGs of Rhizoctonia solani associated with potato in soil and tuber samples in Great Britain. Eur. J. Plant Pathol. 2013, 136, 273-280. [CrossRef]

61. Lees, A.K.; Cullen, D.W.; Sullivan, L.; Nicolson, M.J. Development of conventional and quantitative real-time PCR assays for the detection and identification of Rhizoctonia solani AG-3 in potato and soil. Plant Pathol. 2002, 51, 293-302. [CrossRef]

(C) 2018 by the authors. Licensee MDPI, Basel, Switzerland. This article is an open access article distributed under the terms and conditions of the Creative Commons Attribution (CC BY) license (http:/ / creativecommons.org/licenses/by/4.0/). 